\title{
Maps Showing Thermal Maturity of Upper Cretaceous Marine Shales in the Wind River Basin, Wyoming
}

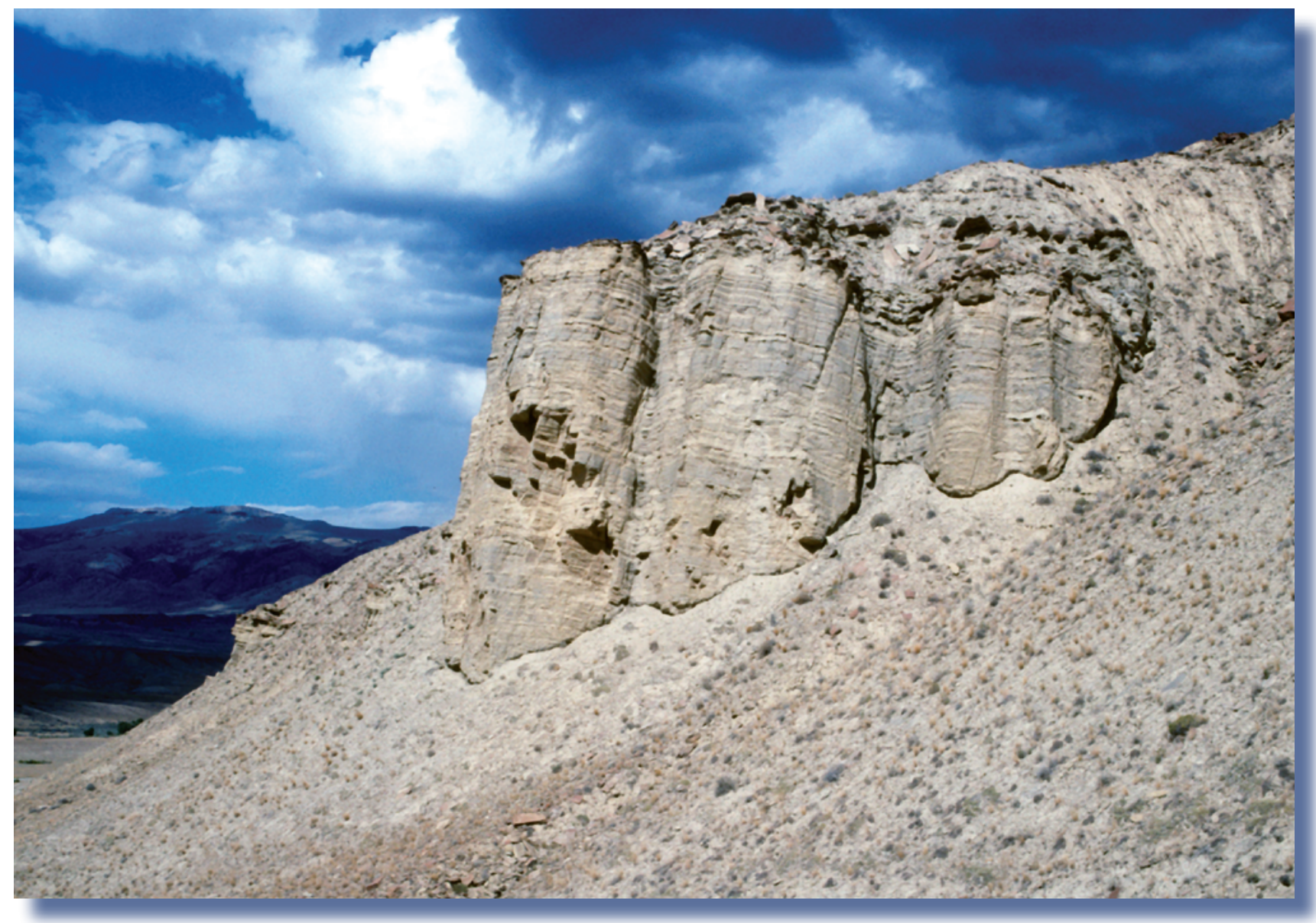

Pamphlet to accompany

Scientific Investigations Map 3266 
COVER. Upper part of the Cody Shale at Eagle Point, Wyo., in the northwestern part of the Wind River Basin. Photograph by R.C. Johnson, 1994. 


\section{Maps Showing Thermal Maturity of Upper Cretaceous Marine Shales in the Wind River Basin, Wyoming}

By Thomas M. Finn and Mark J. Pawlewicz

Scientific Investigations Map 3266 


\section{U.S. Department of the Interior \\ SALLY JEWELL, Secretary}

\section{U.S. Geological Survey \\ Suzette M. Kimball, Acting Director}

\section{U.S. Geological Survey, Reston, Virginia: 2013}

For more information on the USGS — the Federal source for science about the Earth, its natural and living resources, natural hazards, and the environment, visit http://www.usgs.gov or call 1-888-ASK-USGS.

For an overview of USGS information products, including maps, imagery, and publications, visit http://www.usgs.gov/pubprod

To order this and other USGS information products, visit http://store.usgs.gov

Any use of trade, product, or firm names is for descriptive purposes only and does not imply endorsement by the U.S. Government.

Although this report is in the public domain, permission must be secured from the individual copyright owners to reproduce any copyrighted materials contained within this report.

Suggested citation:

Finn, T.M., and Pawlewicz, M.J., 2013, Maps showing thermal maturity of Upper Cretaceous marine shales in the Wind River Basin, Wyoming: U.S. Geological Survey Scientific Investigations Map 3266, 13 p., 1 sheet, scale 1:500,000, http://dx.doi.org/10.3133/sim3266.

ISSN 2329-132X (online 


\section{Contents}

Introduction

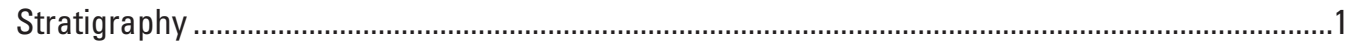

Mowry Shale

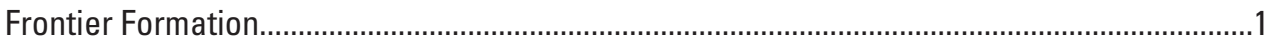

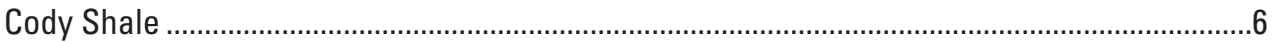

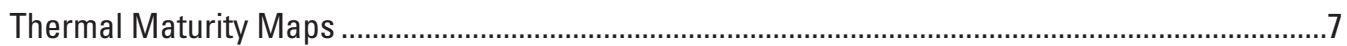

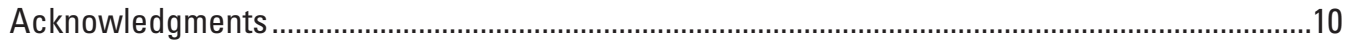

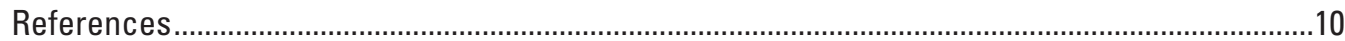

\section{Figures}

1. Map of the Rocky Mountain region showing Laramide basins ..........................................

2. Index map of the Wind River Basin ............................................................................

3. Stratigraphic chart of Upper Cretaceous rocks in the Wind River Basin ..........................4

4. Regional stratigraphic cross section of Cretaceous rocks ...............................................5

5. Type log of Exxon Corp. Poison Springs Unit 1 ..........................................................

6. $\log \left(\mathrm{R}_{\mathrm{o}}\right)$ versus depth plot for the Coastal Oil and Gas 3-8-36-86 Bullfrog Unit well .........8

7. South-north structural cross section, central Wind River Basin ...................................9

\section{Sheet}

Sheet with maps showing thermal maturity of upper Cretaceous marine shales in the

Wind River Basin, Wyoming.

1. Map showing vitrinite reflectance at the top of the Cody Shale, Bighorn Basin, Wyoming and Montana.

2. Map showing vitrinite reflectance at the top of the lower shaly member of the Cody Shale.

3. Map showing vitrinite reflectance at the top of the Mowry Shale. 


\section{Conversion Factors}

Inch/Pound to SI

\begin{tabular}{lcc}
\hline \multicolumn{1}{c}{ Multiply } & By & To obtain \\
\hline cubic foot $\left(\mathrm{ft}^{3}\right)$ & Volume & \\
\hline square mile $\left(\mathrm{mi}^{2}\right)$ & 0.02832 & cubic meter $\left(\mathrm{m}^{3}\right)$ \\
\hline Multiply & Area & square kilometer $\left(\mathrm{km}^{2}\right)$ \\
SI to Inch/Pound & 2.590 & \\
\hline & & To obtain \\
\hline millimeter $\left(\mathrm{mm}^{2}\right)$ & Length & \\
\hline square meter $\left(\mathrm{m}^{2}\right)$ & 0.03937 & inch (in.) \\
square kilometer $\left(\mathrm{km}^{2}\right)$ & Area & \\
\hline
\end{tabular}

Altitude, as used in this report, refers to distance above Sea Level. 


\title{
Maps Showing Thermal Maturity of Upper Cretaceous Marine Shales in the Wind River Basin, Wyoming
}

\author{
By Thomas M. Finn and Mark J. Pawlewicz
}

\section{Introduction}

The Wind River Basin is a large Laramide (Late Cretaceous through Eocene) structural and sedimentary basin that encompasses about 7,400 $\mathrm{mi}^{2}$ in central Wyoming (fig. 1). The basin is bounded by the Washakie Range, Owl Creek, and southern Bighorn Mountains on the north, the Casper arch on the east and northeast, the Granite Mountains on the south, and the Wind River Range on the west (figs. 1, 2).

Important conventional and unconventional oil and gas resources have been discovered and produced from reservoirs ranging in age from Mississippian through Tertiary (Keefer, 1969; Fox and Dolton, 1989, 1996; De Bruin, 1993; Johnson and others, 1996, 2007). It has been suggested that various Upper Cretaceous marine shales are the principal hydrocarbon source rocks for many of these accumulations (Keefer, 1969; Meissner and others, 1984; Fox and Dolton, 1989, 1996; Johnson and Rice, 1993; Nuccio and others, 1996; and Schelling and Wavrek, 1999, 2001). Numerous source rock studies of various Upper Cretaceous marine shales throughout the Rocky Mountain region by various authors, including Schrayer and Zarrella (1963, 1966, 1968), Nixon (1973), Clayton and Swetland (1977), Merewether and Claypool (1980), Burtner and Warner (1984), Hagen and Surdam (1984), Momper and Williams (1984), Davis (1986), Davis and others (1989), Nuccio (1990a,b), Longman and others (1998), Landon and others (2001), Roberts and others (2004, 2007, 2008), and Finn (2007a, 2010), have led to the conclusion that these rocks have generated, or are capable of generating, oil and (or) gas. With recent advances and success in horizontal drilling and multistage fracture stimulation there has been an increase in exploration and completion of wells in these marine shales in other Rocky Mountain Laramide basins that were traditionally thought of only as hydrocarbon source rocks (Sterling and others, 2009; Sonnenberg, 2011). Important parameters that control hydrocarbon production from shales include: reservoir thickness, amount and type of organic matter, and thermal maturity (Milici, 1993; Curtis, 2002; Passey and others, 2010). The purpose of this report is to present maps and a structural cross section showing levels of thermal maturity, based on vitrinite reflectance $\left(R_{o}\right)$, for Upper Cretaceous marine shales in the Wind River Basin.

\section{Stratigraphy}

Figure 3 is a correlation chart showing the stratigraphic nomenclature for Upper Cretaceous marine shales and associated rocks in the Wind River Basin (Finn, 2007b) and correlative units in various localities in the Powder River Basin to the east (Merewether, 1996). The stratigraphic relationships and nomenclature for the Wind River Basin are also illustrated on the regional stratigraphic cross section in figure 4 .

\section{Mowry Shale}

According to Keefer and Johnson (1997), the Mowry Shale in the Wind River Basin is characterized by two distinct units (fig. 5). The lower part consists of 50 to $150 \mathrm{ft}$ of soft fissile clay-rich shale that has been referred to as the Shell Creek Shale in the adjacent Bighorn and Powder River Basins (Eicher, 1962; Burtner and Warner, 1984). The upper part is composed of 200 to $350 \mathrm{ft}$ of hard brittle siliceous shale, with numerous bentonite beds (Keefer and Johnson, 1997). The shales are dark brown to black, organic-rich, and contain an abundance of fish scales (Burtner and Warner, 1984). The bentonites are gray to tan and range in thickness from less than an inch to as much as $6.5 \mathrm{ft}$ (Byers and Larson, 1979). The top of the Mowry is considered to be the Clay Spur Bentonite Bed; the base is the contact with the underlying Muddy Sandstone (fig. 5). The combined thickness of the lower and upper units ranges from about $220 \mathrm{ft}$ in the southeastern part of the basin to more than $500 \mathrm{ft}$ in the western part. Paleontologic evidence and radiometric dating indicates that the formation is mainly early Late Cretaceous (Cenomanian) in age (Cobban and Kennedy, 1989; Merewether and others, 1997; Obradovich and others, 1996), but the lower part (Shell Creek Shale equivalent) has been dated radiometrically as Early Cretaceous (Albian) by Obradovich and others (1996). For convenience, all of the formation will be discussed with the Upper Cretaceous in this report.

\section{Frontier Formation}

The Frontier Formation consists of alternating sandstone, shale, and bentonite that accumulated in marine and marginal marine environments (Keefer, 1972). In the western part of 


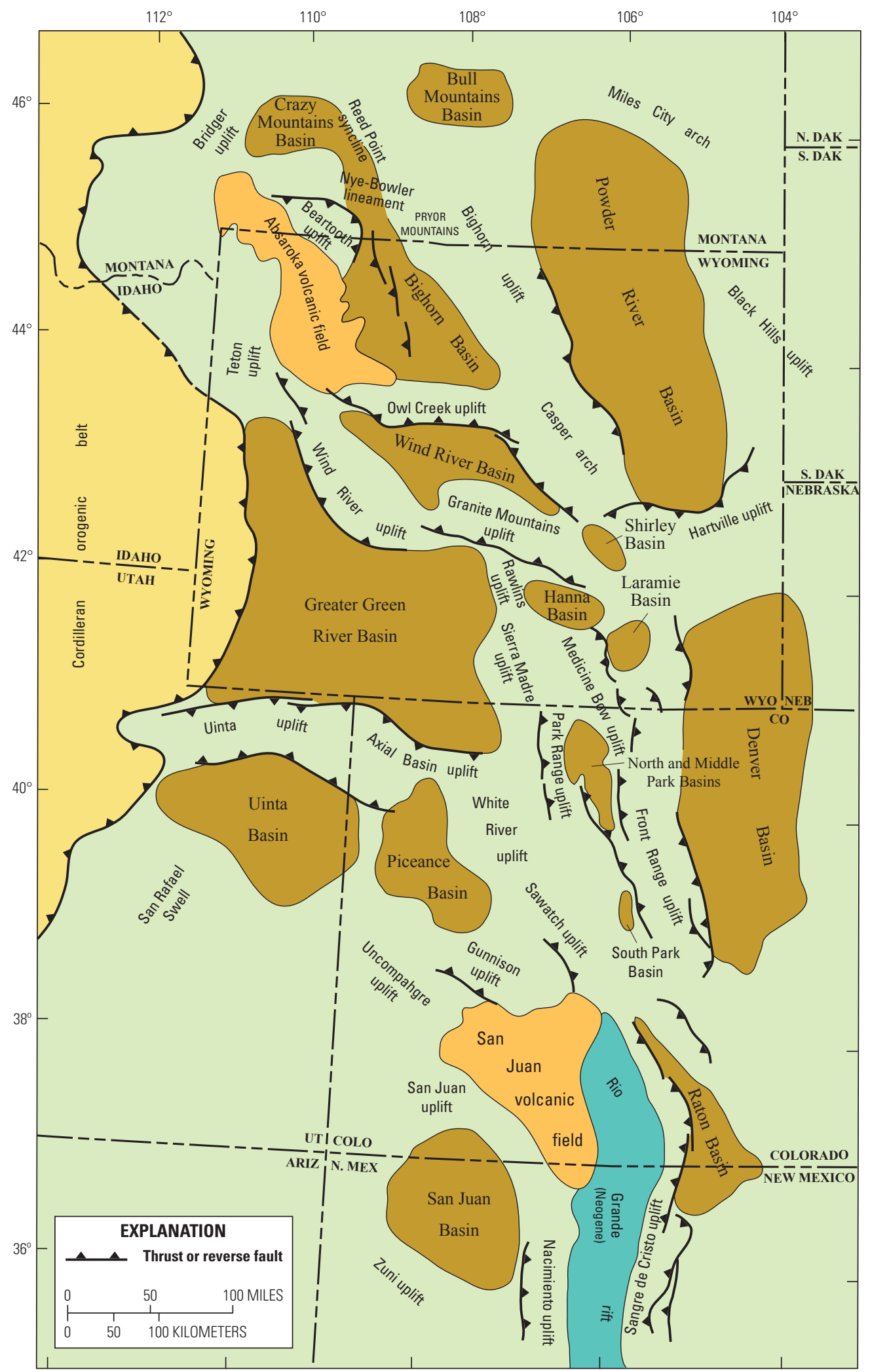

Figure 1. Map of Rocky Mountain region extending from southern Montana to northern New Mexico showing locations of Laramide sedimentary and structural basins (in brown) and intervening uplifts. Modified from Dickinson and others (1988). 


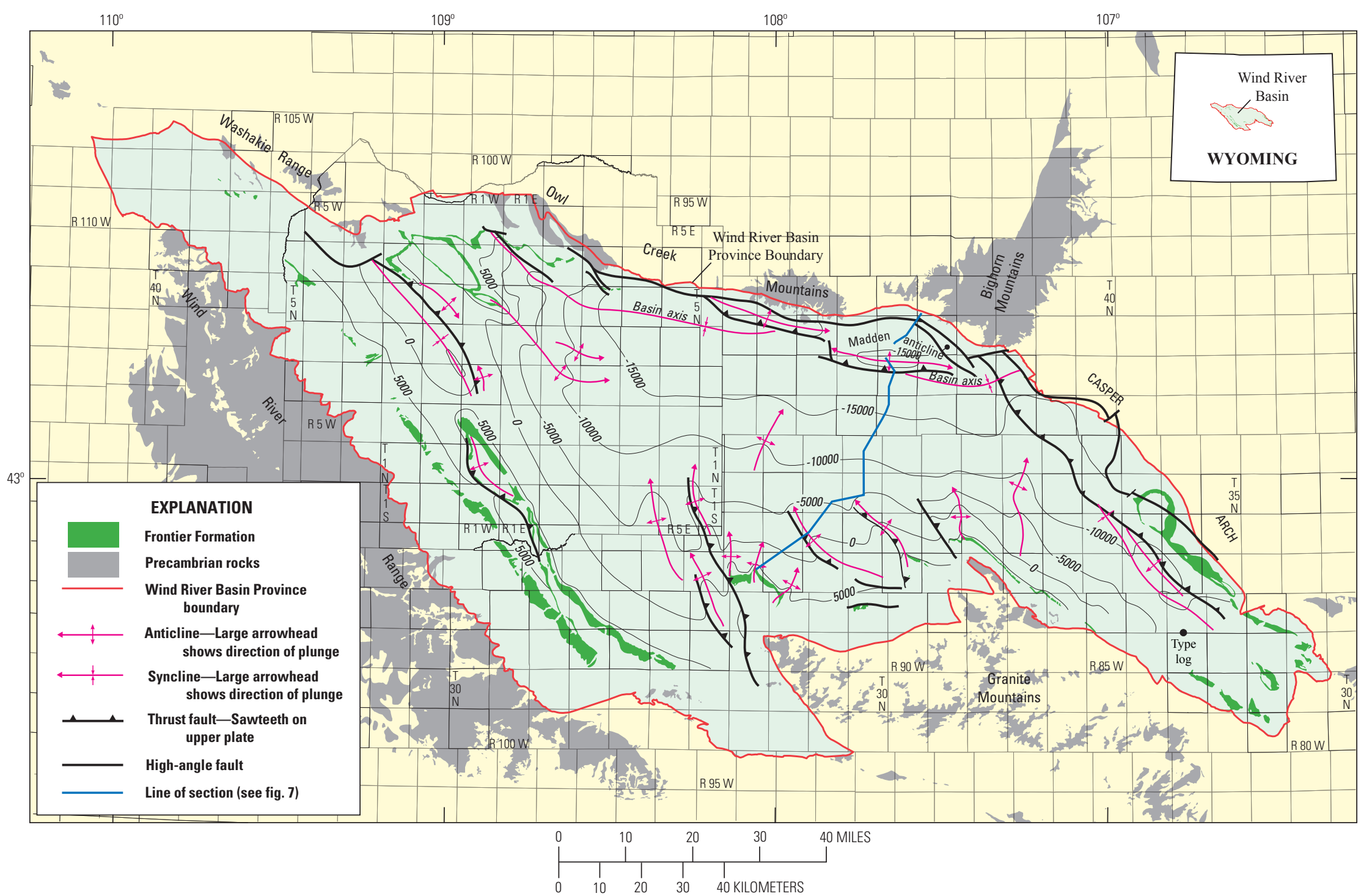

Figure 2. Index map of the Wind River Basin in central Wyoming showing major structural and physiographic features. Structure contours are drawn on top of the Frontier Formation. Contour interval 5,000 ft. 


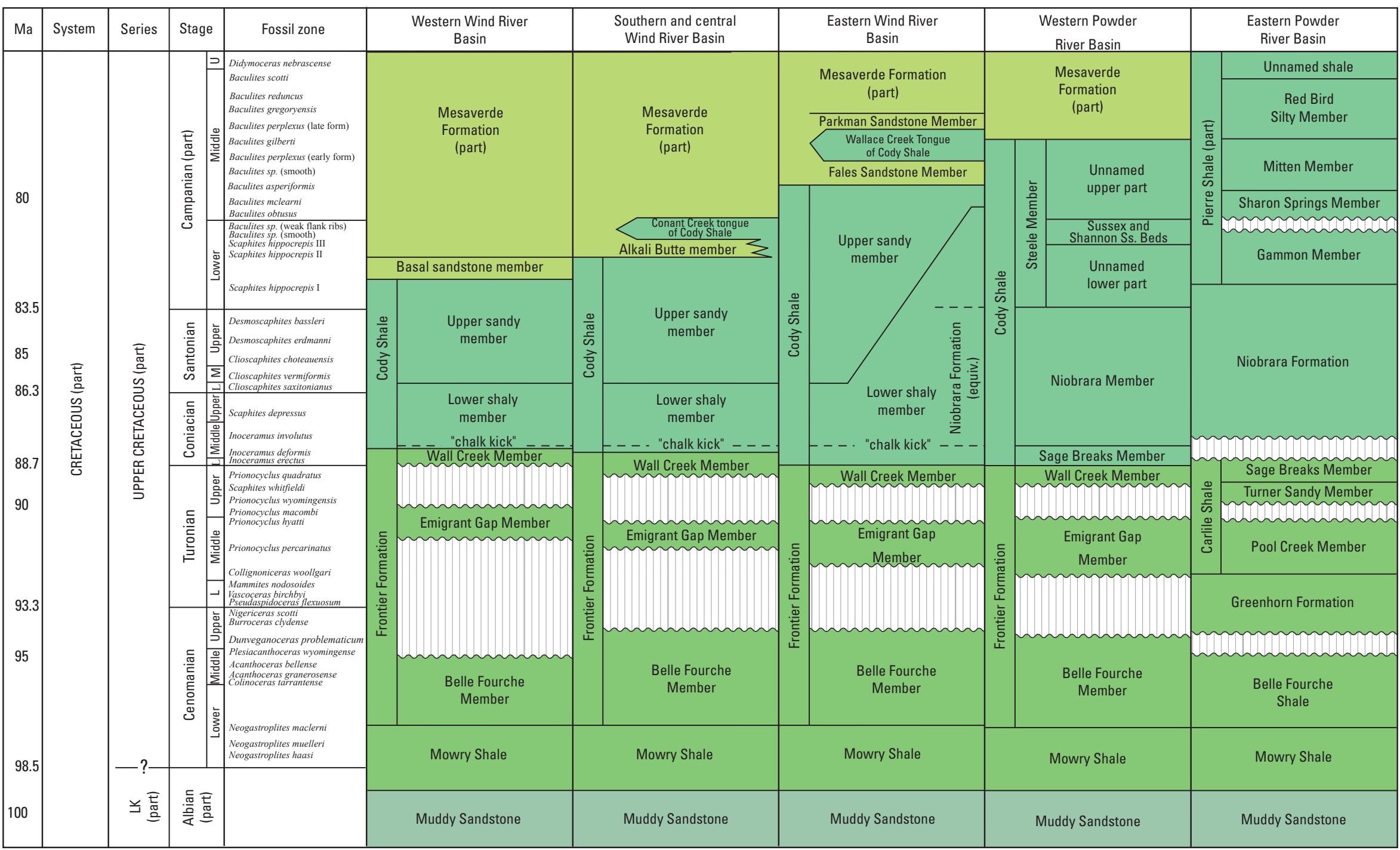

Figure 3. Correlation chart showing stratigraphic relations of lowermost Upper Cretaceous rocks in the Wind River Basin and correlation with equivalent rocks in the Powder River Basin. Modified from Merewether (1996) and Finn (2007b). Radiometric ages and fossil zones are from Obradovich (1993), and Merewether and others (1997). LK, Lower Cretaceous. 


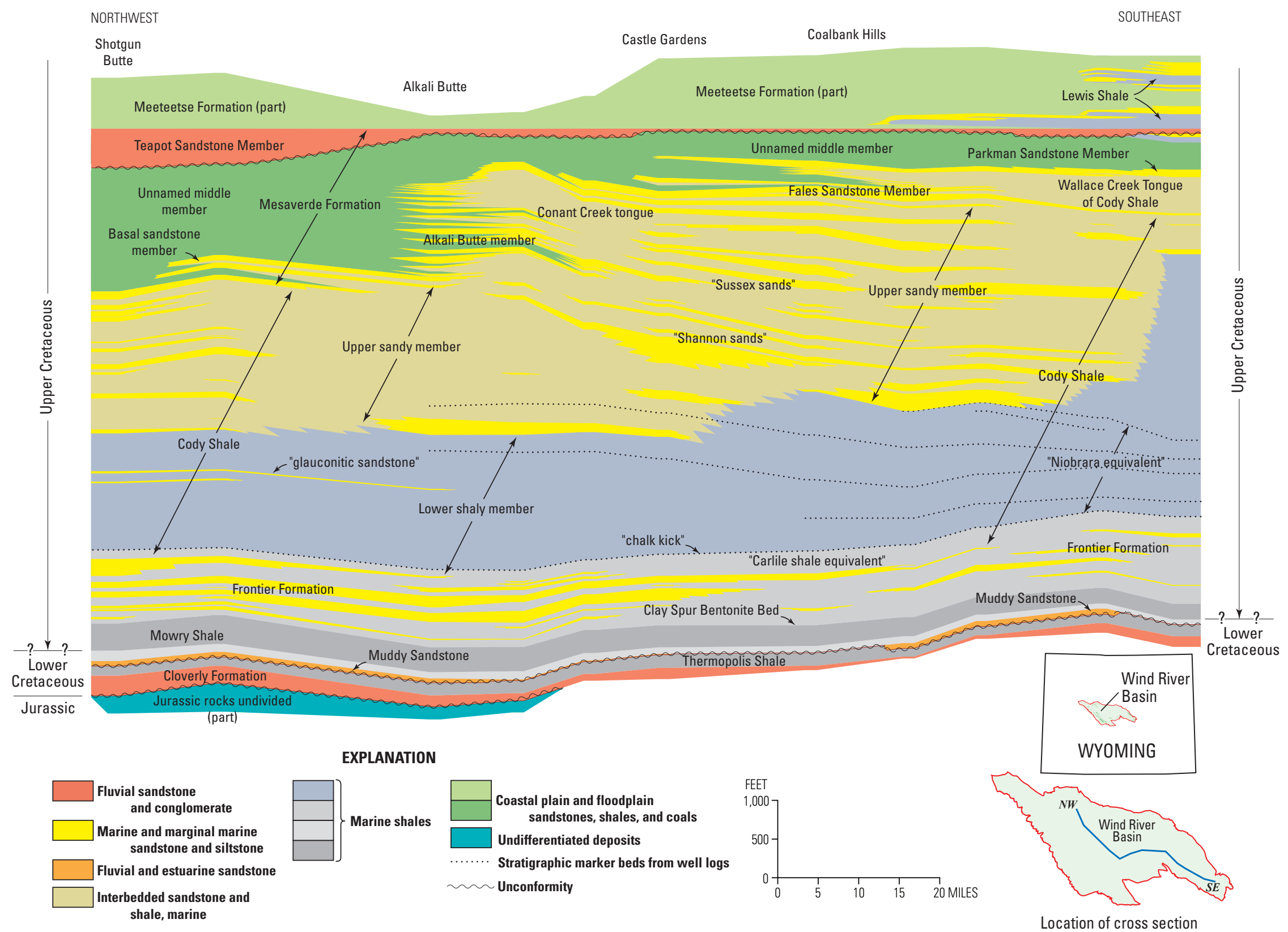

Figure 4. Regional northwest-southeast stratigraphic cross section of Cretaceous rocks (part) in the Wind River Basin. Modified from Finn (2007b). 


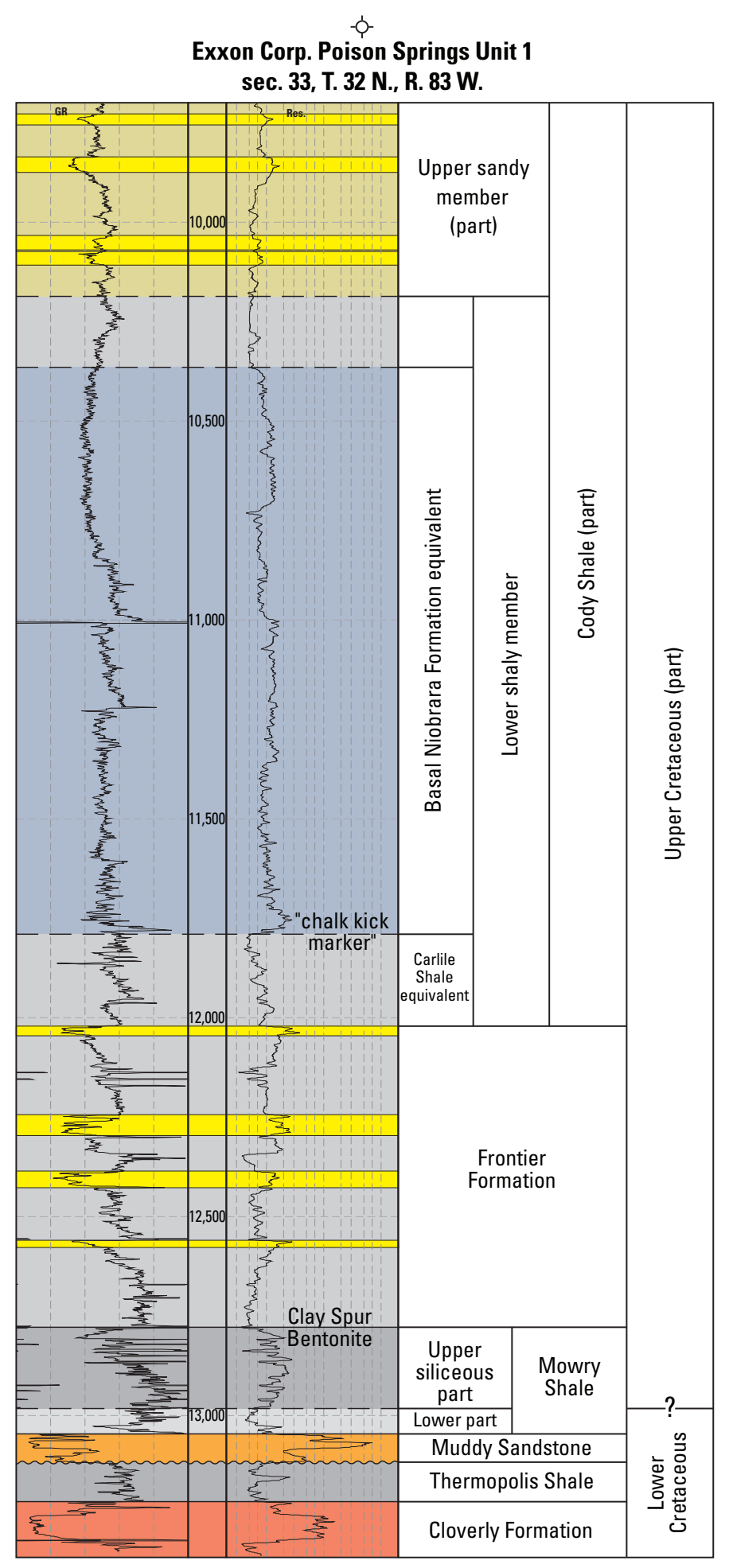

Figure 5, Type log of Exxon Corp. Poison Springs Unit 1, of the lower and lowermost Upper Cretaceous rocks in the southeastern part of the Wind River Basin. Sandstones and conglomerates of predominantly fluvial origin are shown in red; marine and marginal marine sandstones and siltstones, in yellow; marine shales, in various shades of gray; estuarine and fluvial sandstones in orange; interbedded sandstone and shale in tan. Location shown in figure 2. the basin, the Frontier also contains some nonmarine rocks, including minor coal deposits. Sandstones generally dominate in the upper part of the formation, whereas the lower part is mostly marine shale. Many individual sandstones are blanketlike and can be traced over several miles, but locally may be discontinuous and pinch out into marine shale. The shales are generally sandy or silty and vary from gray to black in color. The formation is Cenomanian to Coniacian in age (Merewether and others, 1997) and ranges in thickness from 400 to $800 \mathrm{ft}$.

\section{Cody Shale}

The Cody Shale consists of marine shale, siltstone, and sandstone that were deposited during a major transgressiveregressive cycle that Kauffman (1977) referred to as the "Niobrara Cyclothem." According to Johnson and others (2007) the formation ranges in thickness from about $3,250 \mathrm{ft}$ in the western part of the basin to more than $5,500 \mathrm{ft}$ in the eastern part. The lower and upper contacts are conformable and interfinger with the underlying Frontier and overlying Mesaverde Formations (fig. 4). Four members are recognized in ascending order: (1) the lower shaly member (Thompson and White, 1954; Yenne and Pipiringos, 1954; and Keefer and Troyer, 1964), (2) the upper sandy member (Thompson and White, 1954; Yenne and Pipiringos, 1954; Keefer and Troyer, 1964), (3) the informally named "Conant Creek tongue" (Szmajter, 1993), and (4) the Wallace Creek Tongue (Barwin, 1961) (fig. 4). The age of the Cody ranges from Coniacian to middle Campanian (Keefer, 1972).

The unnamed lower shaly member is about $1,750 \mathrm{ft}$ thick in the western part of the Wind River Basin and thickens to the east to more than $2,250 \mathrm{ft}$ (Johnson and others, 2007). It is comprised of gray to black shale and bentonite deposited in an offshore marine environment. A persistent geophysical-log marker in the lower 100-300 ft of the lower member (fig. 5), referred to as the "chalk kick" by Keefer (1972), can be traced in the subsurface throughout most of the basin; it separates noncalcareous shales in the lower part of the shaly member from overlying calcareous shales. Based on sample descriptions from well cuttings, the calcareous interval is about 1,000 $\mathrm{ft}$ thick in the eastern part of the basin where Merewether and others (1977a, b) correlated it with the Niobrara Formation in the Powder River Basin (fig. 3). They (Merewether and others, 1977a, b) correlated the interval below the "chalk kick" marker and the top of the uppermost sandstone in the Frontier Formation with the Carlile Shale in the Powder River Basin (figs. 4, 5). In the eastern part of the Wind River Basin the Niobrara-equivalent rocks are of Coniacian to latest Santonian or earliest Campanian age. To the west, the upper part of the interval grades into the sandy and shaly facies of the upper sandy member of the Cody Shale and only the basal Niobrara strata of the Powder River Basin are represented by the lower shaly member (fig. 4). In the western part of the Wind River Basin, rocks assigned to the shaly member are Coniacian to early Santonian in age (Yenne and Pipiringos, 1954; Keefer, 1972; Finn, 2007b). 
The upper sandy member ranges in thickness from about $1,800 \mathrm{ft}$ in the western part of the basin to about $3,500 \mathrm{ft}$ in the southeastern part (Johnson and others, 2007). It consists of light to medium gray sandstones and tan and gray shales. Dunleavy and Gilbertson (1986) referred to sandstones in the upper part of the member in the northern part of the basin as the "Sussex" and "Shannon" sandstone beds, which, according to them were deposited "as a near-shore bar complex along the edge of a delta." Like sandstones in the underlying Frontier Formation, many individual sandstones in the upper part of the Cody are blanket-like and can be traced over several miles before pinching out into marine shale. The upper sandy member becomes less distinct in the southeastern part of the basin where it grades laterally into more shaly facies (Finn, 2007b) (fig. 4).

The Conant Creek tongue of the Cody Shale, informally named by Szmajter (1993), trends north-south across the central part of the basin, and is separated from the upper sandy member by an eastward thinning clastic wedge of marginal marine and nonmarine rocks informally referred to as the Alkali Butte member of the Mesaverde Formation by Hogle and Jones (1991) (fig. 4). The Conant Creek tongue is generally 400 to $900 \mathrm{ft}$ thick, but thins to zero where it grades westward into nonmarine rocks of the Mesaverde Formation (fig. 4).

The Wallace Creek Tongue of the Cody Shale occupies the eastern and southeastern parts of the Wind River Basin and is stratigraphically higher and younger than the Conant Creek tongue to the west. It is a westward-thinning tongue of marine shale that separates the Fales Sandstone Member at the base of the Mesaverde Formation from the upper part of the formation (Barwin, 1961) (fig. 4). The Wallace Creek Tongue is nearly $500 \mathrm{ft}$ thick in the southeastern corner of the basin and thins to zero in the northern part of the Coalbank Hills, where it grades into the main part of the Mesaverde Formation (fig. 4).

\section{Thermal Maturity Maps}

Maps showing the levels of thermal maturity based on vitrinite reflectance $\left(\mathrm{R}_{\mathrm{o}}\right)$ for Cretaceous marine shales in the Wind River Basin are shown as three separate maps on the map sheet. They were constructed using $\mathrm{R}_{\mathrm{o}}$ data published by Johnson and others (1991), Barker and Crysdale (1993), Nuccio and others (1993, 1996), Pawlewicz (1993), Finn and others (2006), and Pawlewicz and Finn (2013), from samples collected from wells drilled for oil and gas exploration and production, and from outcrops. For wells that reported $\mathrm{R}_{\mathrm{o}}$ measurements over a range of depths, these data were plotted on a $\log \left(R_{o}\right)$ versus depth plot for each well and a visual best-fit line was drawn through the data (for example, see fig. 6). Data points that appeared to be anomalously high or low with respect to the main trend were disregarded. In some cases, data from closely associated wells were combined into a composite $\log \left(\mathrm{R}_{\mathrm{o}}\right)$ versus depth plot. For a single well or outcrop location where few $R_{0}$ measurements were available over a short depth range or stratigraphic interval, the available data were averaged and the calculated $\mathrm{R}_{\mathrm{o}}$ was plotted for that location.
The three maps presented on the map sheet were constructed to show the thermal maturity of Upper Cretaceous marine shales in the Wind River Basin at: (1) top of the Cody Shale, (2) top of the lower shaly member of the Cody Shale (Niobrara equivalent), and (3) the top of the Mowry Shale.

- Because the contact between the Cody Shale and the overlying Mesaverde Formation rises stratigraphically to the east (figs. 3,4 ), it was necessary to change the contoured interval from west to east across map 1 (top of Cody Shale). In the western part of the basin, the contours are drawn at the base of the basal sandstone member of the Mesaverde Formation. In the central part, they are drawn at the top of the Conant Creek tongue of the Cody Shale, and in the eastern and southeastern parts they are drawn at the top of the Wallace Creek Tongue (figs. 3 and 4; and map 1 on the sheet).

- The $\mathrm{R}_{\mathrm{o}}$ map for the top of the lower shaly member (map 2 on the map sheet) is contoured at the contact between the lower shaly member and the overlying sandy member in the western and central parts of the basin. However, in the eastern and southeastern parts of the basin, these subdivisions are less distinct and the contours are drawn at the top of the Niobrara-equivalent strata based on well log correlations from the Powder River Basin by Merewether and others (1977a, b) (figs. 3 and 4; and map 2 on the map sheet).

- The $\mathrm{R}_{\mathrm{o}}$ map for the Mowry Shale (map 3 on the map sheet) is drawn on the Clay Spur Bentonite Bed (fig. 4).

For all three contoured horizons, the maps show gradual increases in maturity from the margins of the Wind River Basin northward into the deeper parts of the basin, which reflect its structural configuration (fig. 2). In each case, $R_{o}$ values range from less than 0.6 percent along the shallow margins of the basin increasing to greater than 3.0 to 4.0 percent in the deeper parts along the main basin trough and in the area of the Madden anticline near the northern margin of the basin (maps 1-3 on the map sheet). These thermal maturity trends show that large areas of the basin are thermally mature $\left(\mathrm{R}_{\mathrm{o}}>\right.$ about 0.6 percent) to overmature $\left(R_{o}>\right.$ about 1.35 percent $)$ with respect to oil generation based on parameters defined by Peters and Cassa (1994). A structural cross section extending from the Madden anticline south to the southern margin of the basin illustrates the relation between present-day structural configuration of the basin and the levels of thermal maturity (fig. 7). The cross section shows that the isoreflectance lines are nearly horizontal and cut across present-day structures, indicating that the thermal maturation developed mainly after basin formation and deformation during the Laramide orogeny and subsequent accumulation of basin fill (Bustin and others, 1983; Barker and Crysdale, 1993; Nuccio and others, 1996). 
Coastal Oil and Gas 3-8-36-86 Bullfrog Unit sec. 8, T. 36 N., R. 86 W.

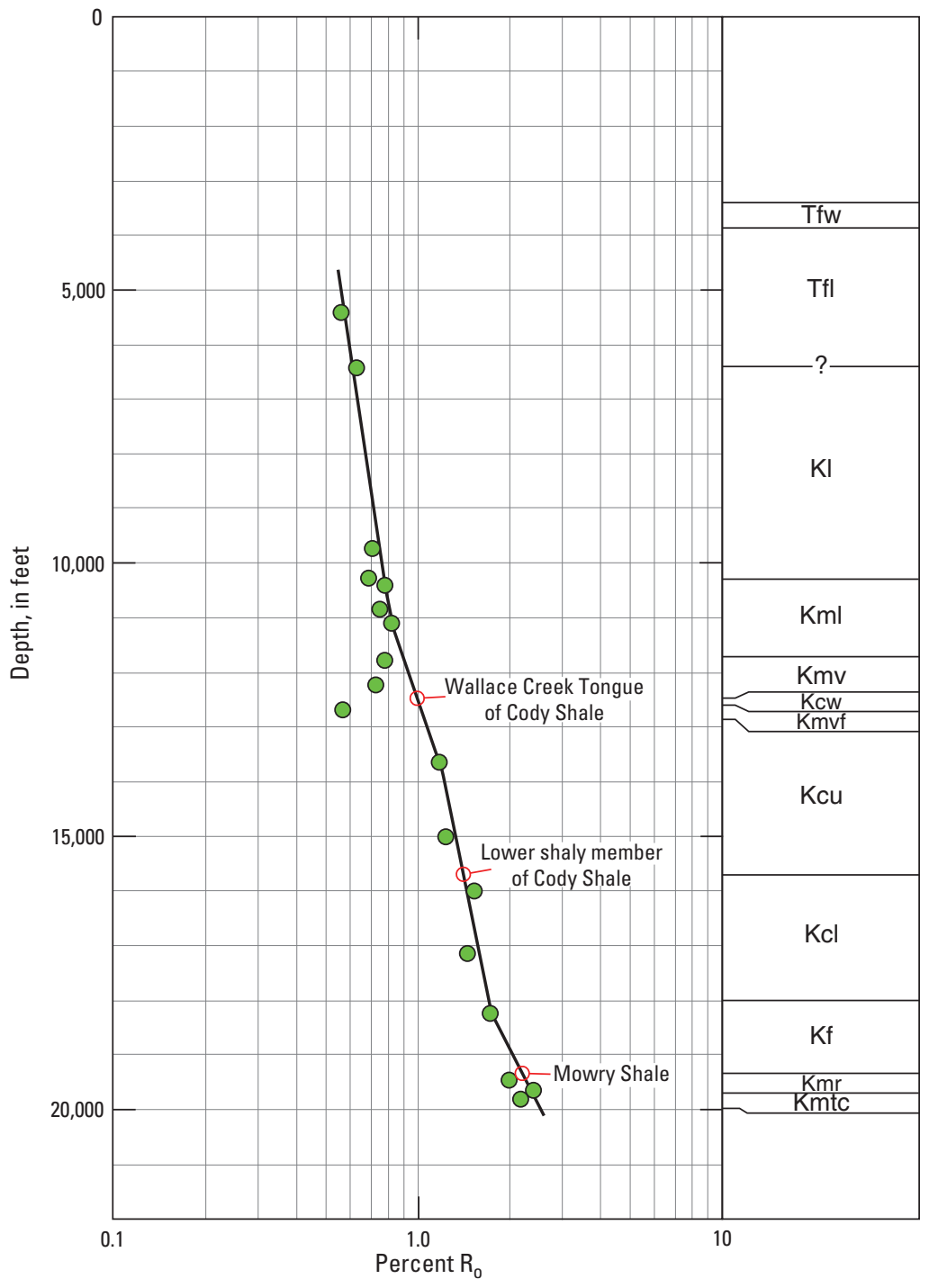

Figure 6. $\log \left(\mathrm{R}_{0}\right)$ versus depth plot for the Coastal Oil and Gas 3-8-36-86 Bullfrog Unit well. Tfw, Waltman Shale Member of Fort Union Formation; Tfl, lower unnamed member of Fort Union Formation; KI, Lance Formation; $\mathrm{Kml}$, Meeteetse Formation and Lewis Shale, undivided; Kmv, Mesaverde Formation; Kcw, Wallace Creek Tongue of Cody Shale; Kmvf, Fales Member of Mesaverde Formation; Kcu, upper sandy member of Cody Shale; Kcl, lower shaly member of Cody Shale; Kf, Frontier Formation; Kmr, Mowry Shale; Kmtc, Muddy Sandstone, Thermopolis Shale, and Cloverly Formation, undivided. 


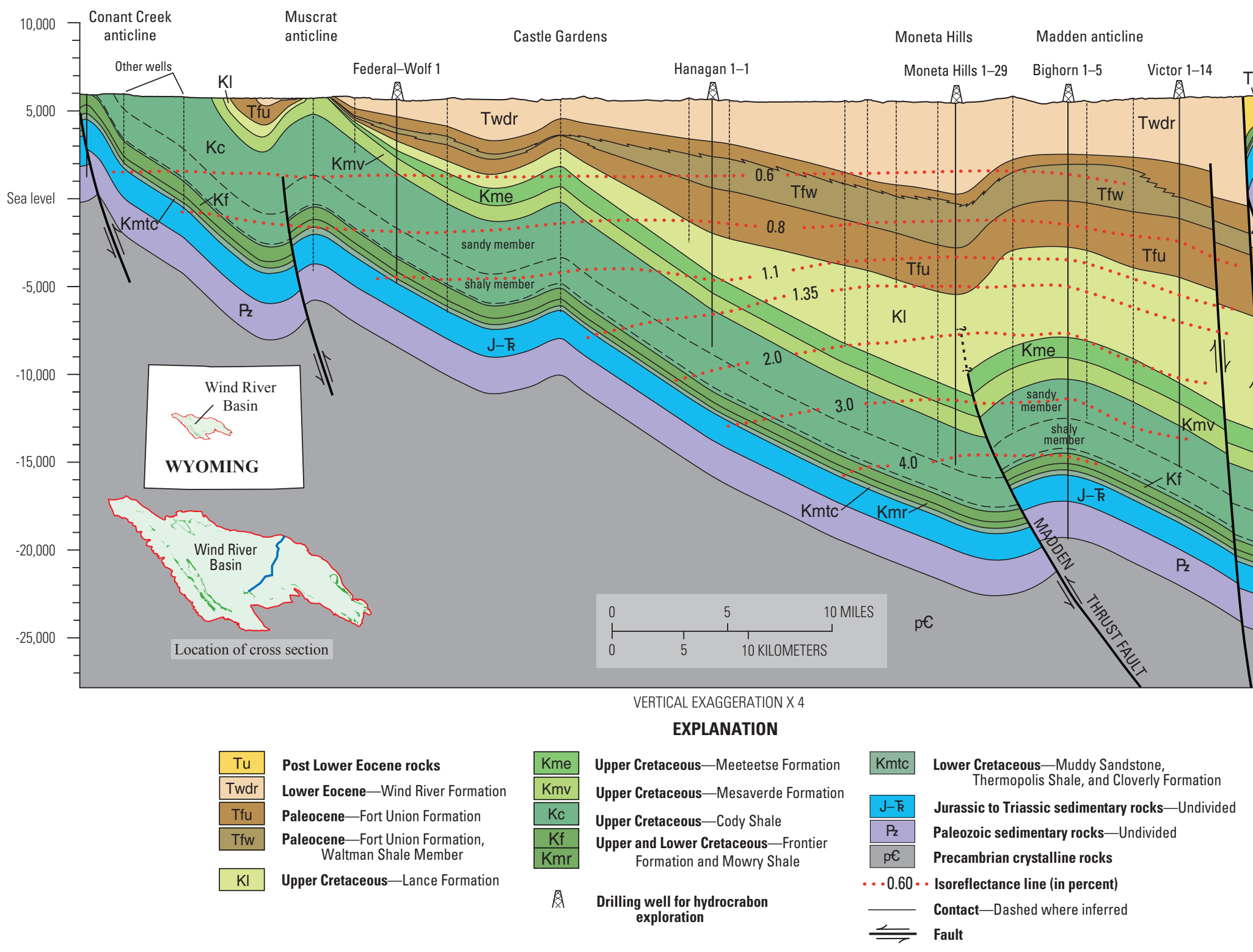

Figure 7. South-north structural cross section across the central part of the Wind River Basin, Wyoming, showing relation between present-day structure and levels of thermal maturity based on vitrinite reflectance. Line of section shown in fig. 2 and on map sheet. The part of the line of section north of the Madden anticline is modified from Ray and Keefer (1985). 


\section{Acknowledgments}

The manuscript and plates benefited from reviews by Dick Keefer, Phil Nelson, Dave Ferderer, and Tom Judkins, and their suggestions and comments are greatly appreciated.

\section{References Cited}

Barker, C.E., and Crysdale, B.L., 1993, Burial and temperature history of gas generation from coaly organic matter in the Late Cretaceous Mesaverde Formation and associated rocks in the deeper portions of the Wind River Basin, Wyoming, in Stroock, Betty, and Andrew, Sam, eds., Jubilee Anniversary $44^{\text {th }}$ Field Conference: Wyoming Geological Association, p. 235-258.

Barwin, J.R., 1961, Stratigraphy of the Mesaverde Formation in the southeastern part of the Wind River Basin, Fremont and Natrona counties, Wyoming: Laramie, Wyo., Master's thesis, University of Wyoming, 78p.

Burtner, R.L., and Warner, M.A., 1984, Hydrocarbon generation in lower Cretaceous Mowry and Skull Creek Shales of the northern Rocky Mountain area, in Woodward, Jane, Meissner, F.F, and Clayton, J.L., eds., Hydrocarbon source rocks of the greater Rocky Mountain region: Rocky Mountain Association of Geologists Guidebook, p. 449-467.

Bustin, R.M., Cameron, A.R., Grieve, D.A., and Kalkreuth, W.D., 1983, Coal petrology, its principles, methods, and applications: Geological Association of Canada, Short Course Notes, v. 3, 230 p.

Byers, C.W., and Larson, D.W., 1979, Paleoenvironments of Mowry Shale (Lower Cretaceous), western and central Wyoming: American Association of Petroleum Geologists Bulletin, v. 63, no. 3, p. 354-361.

Clayton, J.L., and Swetland, P.J., 1977, Preliminary reportPetroleum geochemistry of the Denver Basin, in Veal, H.K., ed., Exploration frontiers of the central and southern Rockies: Rocky Mountain Association of Geologists, p. 223-233.

Cobban, W.A., and Kennedy, W.J., 1989, The ammonite Metengonoceras Hyatt, 1903, from the Mowry Shale (Cretaceous) of Montana and Wyoming: U.S. Geological Survey Bulletin 1787-L, 11 p.

Curtis, J.B., 2002, Fractured shale-gas systems: American Association of Petroleum Geologists Bulletin, v. 86, no. 11, p. 1921-1938.

Davis, H.R., 1986, Amount and type of organic matter in the Cretaceous Mowry Shale of Wyoming: U.S. Geological Survey Open-File Report 86-412, 17 p.
Davis, H.R., Byers, C.W., and Pratt, L.M., 1989, Depositional mechanisms and organic matter in Mowry Shale (Cretaceous), Wyoming: American Association of etroleum Geologists Bulletin, v. 73, no. 9, p. 1103-1116.

De Bruin, R.H., 1993, Overview of oil and gas geology of Wyoming, in Snoke, A.W., Steidtmann, J.R., and Roberts, S.M., eds., Geology of Wyoming: Geological Survey of Wyoming Memoir no. 5, p. 836-873.

Dickinson, W.R., Klute, M.A., Hayes, M.J., Janecke, S.U., Lundin, E.R., McKittrick, M.A., and Olivares, M.D., 1988, Paleogeographic and paleotectonic setting of Laramide sedimentary basins in the central Rocky Mountain region: Geological Society of America Bulletin, v. 100, p. 1023-1039.

Dunleavy, J.M., and Gilbertson, R.L., 1986, Madden anticline-Growing giant, in Noll, J.H., and Doyle, K.M., eds., Rocky Mountain oil and gas fields: Wyoming Geological Association, p. 107-157.

Eicher, D.L., 1962, Biostratigraphy of the Thermopolis, Muddy, and Shell Creek Formations, in Enyert, R.L., and Curry, W.H., III, eds., Symposium on Early Cretaceous rocks of Wyoming and adjacent areas: Wyoming Geological Association 17th Annual Field Conference guidebook, p. 72-93.

Finn, T.M., 2007a, Source rock potential of Upper Cretaceous marine shales in the Wind River Basin, Wyoming, in U.S. Geological Survey Wind River Basin Assessment Team, eds., Petroleum Systems and Geologic Assessment of Oil and Gas Resources in the Wind River Basin Province, Wyoming: U.S. Geological Survey Digital Data Series DDS-69-J, chap. 8, 24 p.

Finn, T.M., 2007b, Subsurface stratigraphic cross sections of Cretaceous and Lower Tertiary rocks in the Wind River Basin, central Wyoming, Wyoming, in U.S. Geological Survey Wind River Basin Assessment Team, eds., Petroleum Systems and Geologic Assessment of Oil and Gas Resources in the Wind River Basin Province, Wyoming: U.S. Geological Survey Digital Data Series DDS-69-J, chap. 9, 28 p.

Finn, T.M., 2010, New source rock data for the Thermopolis and Mowry Shales in the Wyoming part of the Bighorn Basin, in U.S. Geological Survey Bighorn Basin Assessment Team, eds., Petroleum Systems and Geologic Assessment of Oil and Gas in the Bighorn Basin Province, Wyoming and Montana: U.S. Geological Survey Digital Data Series DDS-69-V, chap. 4, 15 p.

Finn, T.M., Roberts, L.N.R., and Pawlewicz, M.J., 2006, Vitrinite reflectance data for the Wind River Basin, central Wyoming: U.S. Geological Survey Open-File Report 2006-1015, 4 p. 
Fox, J.E., and Dolton, G.L., 1989, Petroleum geology of the Wind River and Bighorn Basins, Wyoming and Montana: U.S. Geological Survey Open-File Report 87-450P, 41 p.

Fox, J.E., and Dolton, G.L., 1996, Wind River Basin Province (35); in Gautier, D.L., Dolton, G.L., Takahashi, K.I., and Varnes, K.L., eds., 1995 National assessment of United States oil and gas resources-Results, methodology, and supporting data: U.S. Geological Survey Digital Data Series DDS-30, release 2 .

Hagen, E.S., and Surdam, R.C., 1984, Maturation history and thermal evolution of Cretaceous source rocks of the Bighorn Basin, Wyoming and Montana, in Woodward, Jane, Meissner, F.F., and Clayton, J.L., eds., Hydrocarbon source rocks of the greater Rocky Mountain region: Rocky Mountain Association of Geologists Guidebook, p. 321-338.

Hogle, D.G., and Jones, R.W., 1991, Subsurface geology of Upper Cretaceous and Lower Tertiary coal-bearing rocks, Wind River Basin, Wyoming: The Mountain Geologist, v. 28 , nos. 2 and 3 , p. 13-36.

Johnson, R.C., Barker, C.E., Pawlewicz, M.J., Crysdale, B.L., Clark, A.C., and Rice, D.D., 1991, Preliminary results of coalbed methane assessment of the Wind River Indian Reservation, Wyoming, in Schwochow, S.D., Murray, D.K., and Fahy, M.F., eds., Coalbed methane of western North America: Rocky Mountain Association of Geologists, p. 273-284.

Johnson, R.C., Finn, T.M., Crovelli, R.A., and Balay, R.H., 1996, An assessment of in-place gas resources in lowpermeability Upper Cretaceous and Lower Tertiary sandstone reservoirs, Wind River Basin, Wyoming: U.S. Geological Survey Open-File Report 96-264, 67 p.

Johnson, R.C., Finn, T.M., Kirschbaum, M.A., Roberts, S.B., Roberts, L.N.R., Cook, Troy, and Taylor, D.J., 2007, The Cretaceous-Lower Tertiary Composite Total Petroleum System, Wind River Basin, Wyoming, in U.S. Geological Survey Wind River Basin Province Assessment Team, eds., Petroleum Systems and Geologic Assessment of Oil and Gas Resources in the Wind River Basin Province, Wyoming: U.S. Geological Survey Digital Data Series DDS-69-J, chap. 4, 96 p.

Johnson, R.C., and Rice, D.D., 1993, Variations in composition and origins of gases from coal bed and conventional reservoirs, Wind River Basin, Wyoming, in Keefer, W.R., Metzger, W.J., and Godwin, L.H., eds., Oil and gas and other resources of the Wind River Basin, Wyoming: Wyoming Geological Association, Special Symposium, p. 319-335.
Kauffman, E.G., 1977, Geological and biological overviewWestern Interior Cretaceous basin, in Kauffman, E.G., ed., Cretaceous facies, faunas, and paleoenvironments across the Western Interior Basin: The Mountain Geologist, v. 14, nos. 3 and 4, p. 75-99.

Keefer, W.R., 1969, Geology of petroleum in the Wind River Basin, central Wyoming: American Association of Petroleum Geologists Bulletin, v. 53, no. 9, p. 1839-1865.

Keefer, W.R., 1972, Frontier, Cody, and Mesaverde Formations in the Wind River and southern Bighorn Basins, Wyoming: U.S. Geological Survey Professional Paper 495-E, 23 p.

Keefer, W.R., and Johnson, R.C., 1997, Stratigraphy and correlation of Cretaceous and Paleocene rocks, west-central Wind River Basin, Wyoming, U.S. Geological Survey Oil and Gas Investigations Chart OC-146-B.

Keefer, W.R., and Troyer, M.L., 1964, Geology of the Shotgun Butte area, Fremont County, Wyoming: U.S. Geological Survey Bulletin 1157, 123 p.

Landon, S.M., Longman, M.W., and Luneau, B.A., 2001, Hydrocarbon source rock potential of the Upper Cretaceous Niobrara Formation, Western Interior Seaway of the Rocky Mountain region: The Mountain Geologist, v. 38, no. 1, p. 1-18.

Longman, M.W., Luneau, B.A., and Landon, S.M., 1998, Nature and distribution of Niobrara lithologies in the Cretaceous Western Interior Seaway of the Rocky Mountain Region: The Mountain Geologist, v. 35, no. 4, p. 137-170.

Meissner, F.F., Woodward, Jane, and Clayton, J.L., 1984, Stratigraphic relationships and distribution of source rocks in the greater Rocky Mountain region, in Woodward, Jane, Meissner, F.F., and Clayton, J.L., eds., Hydrocarbon source rocks of the greater Rocky Mountain region: Rocky Mountain Association of Geologists Guidebook, p. 1-34.

Merewether, E.A., 1996, Stratigraphy and tectonic implications of Upper Cretaceous rocks in the Powder River Basin, northeastern Wyoming and southeastern Montana: U.S. Geological Survey Bulletin 1917-T, 92 p.

Merewether, E.A., and Claypool, G.E., 1980, Organic composition of some Upper Cretaceous shale, Powder River Basin, Wyoming: American Association of Petroleum Geologists Bulletin, v. 64, no. 4, p. 488-500.

Merewether, E.A., Cobban, W.A., Matson, R.M., and Magathan, W.J., 1977a, Stratigraphic diagrams with electric logs of Upper Cretaceous rocks, Powder River Basin, Natrona, Converse, and Weston Counties, Wyoming: U.S. Geological Survey Oil and Gas Investigations Map OC-74. 
Merewether, E.A., Cobban, W.A., Matson, R.M., and Magathan, W.J., 1977b, Stratigraphic diagrams with electric logs of Upper Cretaceous rocks, Powder River Basin, Natrona, Converse, and Niobrara counties, Wyoming: U.S. Geological Survey Oil and Gas Investigations Map OC-75.

Merewether, E.A., Dolson, J.C., Hanson, W.B., Keefer, W.R., Law, B.E., Mueller, R.E., Ryer, T.A., Smith, A.C., Stilwell, D.P., and Wheeler, D.M., 1997, Cretaceous stratigraphy in a northeast-trending transect, northern Utah to south-central South Dakota: U.S. Geological Survey Geologic Investigations Map I-2609.

Milici, R.C., 1993, Autogenic gas (self sourced) from shalesAn example from the Appalachian Basin, in Howell, D.G., ed., The future of energy gases: U.S. Geological Survey Professional Paper 1570, p. 253-278.

Momper, J.A., and Williams, J.A., 1984, Geochemical exploration in the Powder River Basin, in Demaison, Gerard, and Murris, R.J., eds., Petroleum geochemistry and basin evaluation: American Association of Petroleum Geologists Memoir 35, p. 181-191.

Nixon, R.P., 1973, Oil source beds in Cretaceous Mowry Shale of northwestern interior United States: American Association of Petroleum Geologists Bulletin, v. 57, no. 1, p. 136-161.

Nuccio, V.F., 1990a, Burial, thermal, and petroleum generation history of the Upper Cretaceous Steele Member of the Cody Shale (Shannon Sandstone Bed horizon), Powder River Basin, Wyoming: U.S. Geological Survey Bulletin 1917-A, $17 \mathrm{p}$.

Nuccio, V.F., 1990b, Determination of source-rock thermal maturity by direct measurements and predictive modelingapplication to Upper Cretaceous Cody Shale, Powder River Basin, Wyoming, in Nuccio, V.F., and Barker, C.E., and Dyson, S.J., eds., Applications of thermal maturity studies to energy exploration: Rocky Mountain Section Society of Economic Paleontologists and Mineralogists, p. 167-175.

Nuccio, V.F., Finn, T.M., and Johnson, R.C., 1996, Thermal maturity data for the assessment of gas resources in the Wind River Basin, Wyoming: U.S. Geological Survey Open-File Report 96v064, $57 \mathrm{p}$.

Nuccio, V.F., Finn, T.M., and Pawlewicz, M.J., 1993, Surface vitrinite reflectance study of the Wind River Basin, central Wyoming, in Keefer, W.R., Metzger, W.J., and Godwin, L.H., eds., Oil and gas and other resources of the Wind River Basin: Wyoming Geological Association Special Symposium, p. 307-317.

Obradovich, J.D., 1993, A Cretaceous time scale, in Caldwell, W.G.E., and Kauffman, E.G., eds., Evolution of the Western Interior Basin: Geological Association of Canada Special Paper 39, p. 379-396.
Obradovich, J.D., Cobban, W.A., Merewether, E.A., and Weimer, R.J., 1996, A time framework for the late Albanian and early Cenomanian strata of northern Wyoming and Montana: Geological Society of America Abstracts with Programs, 1996 Annual Meeting, Denver, Colo., v. 28, no. 7, p. A-66.

Passey, Q.R., Bohacs, K.M., Esch, W.L., Klimentidis, Robert, and Sinha, Somnath, 2010, From oil-prone source rock to gas-producing shale reservoir-Geologic and petrophysical characterization of unconventional shale-gas reservoirs: Society of Petroleum Engineers Paper 131350, 29 p.

Pawlewicz, M.J., 1993, Vitrinite reflectance and geothermal gradients in the Wind River Basin, in Keefer, W.R., Metzger, W.J., and Godwin, L.H., eds., Oil and gas and other resources of the Wind River Basin: Wyoming Geological Association Special Symposium, p. 295-306.

Pawlewicz, M.J., and Finn, T.M., 2013, New vitrinite reflectance data for the Wind River Basin, Wyoming: U.S. Geological Survey Open-File Report 2013-1002, 11 p.

Peters, K.E., and Cassa, M.R., 1994, Applied source rock geochemistry, in Magoon, L.B., and Dow, W.G., eds., The petroleum system - From source to trap: American Association of Petroleum Geologists Memoir 60, p. 93-120.

Ray, R.R., and Keefer, W.R., 1985, Wind River Basin, central Wyoming, in Gries, R.R., and Dyer, R.C., eds., Seismic Exploration of the Rocky Mountain Region: Rocky Mountain Association of Geologists, and Denver Geophysical Society, p. 201-212.

Roberts, L.N.R., Finn, T.M., Lewan, M.D., and Kirschbaum, M.A., 2007, Burial history, thermal maturity, and oil and gas generation history of petroleum systems in the Wind River Basin province, central Wyoming, in U.S. Geological Survey Wind River Basin Assessment Team, eds., Petroleum Systems and Geologic Assessment of Oil and Gas Resources in the Wind River Basin Province, Wyoming: U.S. Geological Survey Digital Data Series DDS-69-J, chap. 6,26 p.

Roberts, L.N.R., Finn, T.M., Lewan, M.D., and Kirschbaum, M.A., 2008, Burial history, thermal history, and oil and gas generation history of source rocks in the Bighorn Basin, Wyoming and Montana: U.S. Geological Survey Scientific Investigations Report 2008-5037, 28 p.

Roberts, L.N.R., Lewan, M.N., and Finn, T.M., 2004, Timing of oil and gas generation of petroleum systems in the Southwestern Wyoming Province: The Mountain Geologist, v. 41, no. 3 , p. $87-118$.

Schelling, D.D., and Wavrek, D.A., 1999, Structural geology and petroleum systems of the Madden field, Wind River Basin, Wyoming: American Association of Petroleum Geologists, v. 83, no. 13 (supplement). 
Schelling, D.D., and Wavrek, D.A., 2001, Structural geology and petroleum systems of the northwestern Wind River Basin, Wyoming: American Association of Petroleum Geologists, v. 85, no. 13 (supplement).

Schrayer, G.J., and Zarrella, W.M., 1963, Organic geochemistry of shale-I Distribution of organic matter in the siliceous Mowry Shale of Wyoming: Geochimica et Cosmochimica Acta, v. 27, no. 10, p. 1033-1046.

Schrayer, G.J., and Zarrella, W.M., 1966, Organic geochemistry of shale-II Distribution of extractable organic matter in the siliceous Mowry Shale of Wyoming: Geochimica et Cosmochimica Acta, v. 30, no. 4, p. 415-434.

Schrayer, G.J., and Zarrella, W.M., 1968, Organic carbon in Mowry Formation and its relation to the occurrence of petroleum in Lower Cretaceous reservoir rocks, in Wulf, G.R., ed., Black Hills area South Dakota, Montana, Wyoming: Wyoming Geological Association, $20^{\text {th }}$ Field Conference Guidebook, p. 35-39.

Sonnenberg, S.A., 2011, The Niobrara Petroleum SystemA new resource play in the Rocky Mountain Region, in Estes-Jackson, J.E., and Anderson, D.S., eds., Revisiting and revitalizing the Niobrara in the central Rockies: Rocky Mountain Association of Geologists, p. 13-32.

Sterling, R., Silverman, M., and Stewart, G., 2009, The Mowry Shale, review of potential in the Bighorn Basin, in Unconventional reservoirs-Oil and gas shales and CBM, Sept. 14, 2009, Denver, Colo: Denver, Colo., Rocky Mountain Association of Geologists and PTTC (Petroleum Technology Transfer Council) fall symposium., $1 \mathrm{p}$.

Szmajter, R.J., 1993, Subsurface stratigraphic cross section of Lower and Upper Cretaceous rocks in the south-central Wind River Basin, Wyoming, in Keefer, W.R., Metzger, W.J., and Godwin, L.H., eds., Oil and gas and other resources of the Wind River Basin, Wyoming: Wyoming Geological Association, Special Symposium, p. 87-90.

Thompson, R.M., and White, V.L., 1954, Geology of the Riverton area, central Wyoming: U.S. Geological Survey Oil and Gas Investigations Map OM-127.

Yenne, K.A., and Pipiringos, G.N., 1954, The Cody Shale and younger Cretaceous and Paleocene rocks in the Wind River Basin, Fremont County, Wyoming: U.S. Geological Survey Oil and Gas Investigations Chart OC-49.
Publishing support provided by:

Denver Publishing Service Center

For more information concerning this publication, contact: Center Director, USGS Central Energy Resources Science Center Box 25046, Mail Stop 939 Denver, CO 80225

(303) 236-1647

Or visit the Central Energy Resources Science Center Web site at: http://energy.usgs.gov/ 


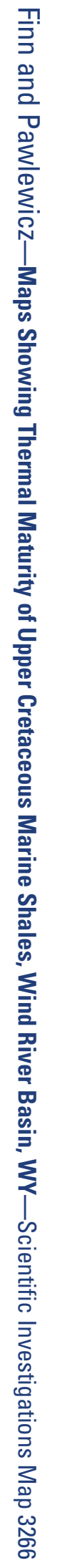

